BNL- 75530 -2006-IR

\title{
Sodium Polyphosphate-Modified Class C/Class F Fly Ash Blend Cements: for Geothermal Wells
}

\author{
Tisugama \\ Energy Science \& Technology Department \\ Brookhaven National Laboratory: \\ Upton; NV 11973:5000 . \\ sugama@bnl.gov \\ L.E. Brothers \\ Halliburton: \\ 2600 S: $2^{\text {nd }}$ Street \\ P.0. Drawer 1431 \\ Duncan; OK 73536 \\ Lance:Brothers@halliburton.com \\ D. Kaspereit \\ CalEnergy Operating Corporation \\ 7030 Gentry Rd. \\ Calipatria, CA 92233 \\ Dennis.kaspereit@calenergy:com
}

February 2006

Notice: This manuscript has been authored by employees of Brookhaven Science Associates, LIC under Contract No:DE-AC02-98CH10886 with the U.S. Department of Energy. The publisher by accepting the manuscript for publication acknowledges that the United States Government retains a non-exclusive; paid-up, irrevocable; world-wide license to publish or reproduce the published form of this manuscript; or allow others: to do so; for, United States Government purposes 


\section{DISCLAIMER}

This report was prepared as an account of work sponsored by an agency of the United States Government: Neither the United States Government nor any: agency thereof, nor any of their employees; nor any of their contractors, subcontractors; or their employees, makes any warranty, express or implied, or: assumes any legal liability or responsibility for the accuracy; completeness, or any third party's use or the results of such use of any information, apparatus, product, or process disclosed or represents that its use would not infringe privately owned rights Reference herein to any specific commercial product process; or service by trade name, trademark, manufacturer, or otherwise, does not necessarily constitute or imply its; endorsement; recommendation; or favoring by the United States: Government or any agency thereof or its contractors or subcontractors. The views and opinions of authors expressed herein: do not necessarily state or reflect those of the United States Government or any agency thereof: 


\section{Abstract}

We investigated the usefullness of the coal-combustion by-products, Class $\mathrm{C}$ fly: ash (C) and Cläs F $\mathrm{F}$ fly ash ( $\mathrm{F}$ ), in developing cost-effective acid-resistant phosphate-based cements for geothermal wells: In the temperature range of $20-100^{\circ} \mathrm{C}$, sodium polyphosphate $(\mathrm{NaP})$ as the acidic cement-forming solution preferentially reacted with calcium sulfate and lime in the $C$ as the base solid reactant through the exothermic acidbase reaction route, rather than with the tricalcium aluminate in $\mathrm{C}$. This reaction led to .... the formation of hydroxyapatite (HOAp). In contrast there was no acid-base reaction between the $\mathrm{F}$ as the acidic solid reactant and $\mathrm{NaP}$. After autoclaving the cements at : : $250^{\circ} \mathrm{C}$, a: well crystallized HOAp phase was formed in the $\mathrm{NaP}$-modified.C cement that was responsible for densifying the cement's structure; thereby conferring!low water : permeability and good compressive strength on the cement. However, the HOAp was susceptible to hot $\mathrm{CO}_{2}$ laden $\mathrm{H}_{2} \mathrm{SO}_{4}^{*}$ solution:( $\left.\mathrm{pH} 1.1\right)$, allowing some acid erosion of the cement: On the other hand; the mullite in F hydrothermally reacted with the $\mathrm{Na}$ from $\mathrm{NaP}$ to form the analcime phase Although this phase played a pivotal role in abating acid erosion, its generation created an undesirable porous structure in the cement. We demonstrated that blending fly ash with a $\mathrm{C} / \mathrm{F}$ ratio of $70 / 30$ resulted in the most suitable properties for acid resistant phosphäte based cement systems: 


\section{Introduction}

In our previous studies on: the hydrothermal synthësis and characterization of sodium polyphosphäte-modified:Class:F fly:ash/calciüm aluminate blend (SFCB) geothermal well cement; we found that four crystalline hydrothermal reaction products, the hydroxyapatite $\left[\left(\mathrm{Ca}_{3}\left(\mathrm{PO}_{4}\right)_{3}(\mathrm{OH}), \mathrm{HO} A \mathrm{Ap}\right]\right.$, boelimite $(\gamma-\mathrm{AlOOH})$, hydrogarnet (3CaO $\left.\mathrm{Al}_{2} \mathrm{O}_{3} \cdot 6 \mathrm{H}_{2} \mathrm{O}\right)$, and zeolite: $\left[\mathrm{Na}-\mathrm{P}\right.$ type, $\mathrm{Na}_{3} \mathrm{Al}_{3} \mathrm{Si}_{5} \mathrm{O}_{16} \cdot 6 \mathrm{H}_{2} \mathrm{O}$ and analcime; $\mathrm{NaAlSi}_{2} \mathrm{O}_{6} \mathrm{H}_{2} \mathrm{O}$ )] phases, were responsible for strengthening the cement autoclaved at temperatures from $100:$ to 300 : $\mathrm{C}$, they also were instrumental in alleviating carbonation by $\mathrm{CO}_{2}(>40,000 \mathrm{ppm})$ andierosion by mildacid brine $(\mathrm{pH} \sim 5)$ [1-4] The HOAp phase: was:formedin a two-step reaction pathway: The first step was an exothermic acid-base reaction:between calcium cation $\left(\mathrm{Ca}^{2+}\right)$ liberated from the calcium aluminate cement (CAC) as the proton-accepting cation-leachable solid base reactant, and"sodium dihydrogen phosphate, $\mathrm{Na}^{+} \mathrm{H}_{2}\left(\mathrm{PO}_{4}\right)$; , derived from the hydrolysis of the sodium polyphosphate:(NäP) as the proton-donating acid reactant at room temperature, to generate amorphous dibasic calcium phosphate-hydrate, $\mathrm{Ca}\left(\mathrm{HPO}_{4}^{4}\right) \times \mathrm{x}_{2} \mathrm{O}$. The second step:was the hydrothermal reaction of $\mathrm{Ca}\left(\mathrm{HPO}_{4}^{*}\right) \mathrm{xH}_{2} \mathrm{O}$ with additional $\mathrm{Ca}^{2+}$ and $\mathrm{Na}^{+} \mathrm{H}_{2}\left(\mathrm{PO}_{4}^{*}\right)$ hydrolysate species; thereby:yeilding HOAp Concurrently, the decalcified CAC was converted into amorphous aluminum oxide hydrate at room:temperature; föllowed by its hydrothermally induced transformation:into crystalline boehmite. The: chemical affinity of amorphous aluminum oxide hydrate with two hydrolysate species; $\mathrm{Cä}^{2+}$ and $\mathrm{OH}$, also yielded the hydrogarnet phase.

Meanwhile, the uptake of $\mathrm{Na}^{+}$dissociated from: $\mathrm{NaP}$ by the mullite $\left(3 \mathrm{Al}_{2} \mathrm{O}_{3}: 2 \mathrm{SiO}_{2}\right)$ reactant in the Class $\mathrm{F}$ fly ash generated an additional crystalline: Na-P type zeolite phase at the hydrothermal temperature of $150^{\circ} \mathrm{C}$. Raising the temperature to: $300 \%$ C led to the Na-P type $\rightarrow$ analcime phase transition:

Regarding the chemistry of CAC as the starting material, two calcium aluminate: compounds monocalciumaluminate $\left(\mathrm{CaO}, \mathrm{Al}_{2} \mathrm{O}_{3}, \mathrm{CA}\right)$ and calcium bialuminate $\left(\mathrm{CaO} \cdot 2 \mathrm{Al}_{2} \mathrm{O}_{3}, \mathrm{CA}_{2}\right)$, and one calcium aluminate silicate, gehlënite $\left(2 \mathrm{CaO} \cdot \mathrm{Al}_{2} \mathrm{O}_{3}: \mathrm{SiO}_{2}\right.$, ; $\mathrm{C}_{2} \mathrm{AS}$ ); in the $\mathrm{CAC}$ played an important role in promoting the generation of these reaction products: However, one intriguing:question remained unanswered: Are other calcium ... aluminate:compounds; such as tricalcium aluminate $\left(3 \mathrm{CaO} \cdot \mathrm{Al}_{2} \mathrm{O}_{3}, \mathrm{C}_{3} \mathrm{~A}\right)$, in the cement; 
effective in deriving these reaction products as are $\mathrm{CA}$ and $\mathrm{CA}_{2}$. As is well documented. $[5 ; 6]$;in: Cläss $\mathrm{C}$ fly: ash as the coal combustion by-products; $\mathrm{C}_{3} \mathrm{~A}$ coexists: with other chemical compounds; such as quartz; ;lime; and calcium sulfate. We deemed it worthwhile: to investigate the usefulness of Class $\mathrm{C}$ fly ash as replacement for:CAC because not only doesthis confer an economical advantage in making the SFCB cement, but:it also:abates anash disposal problem.

Thus; the current study was directed toward investigating the characteristics of the sodium polyphosphate-modified Class: Fifly ash/Class C fly ash bend cements after autoclaving them: $250^{\circ} \mathrm{C}$ for their use as acid-resistant geothermal well cements: Among the characteristics to be:investigated were the $\mathrm{pH}$ values of the pore solution in the cement slurries; the:total energy generated in exothermal acid-base reactions of cement slürries along with a quantitative analysis of reaction product responsible for the total output of this reaction energy, the:porosity, water permeability and compressive strength of autoclaved cements: We also dentified the crystalline phases assembled:in autoclaved cement:bodies. All the data obtained were integrated and correlated directly. with the information on the resistance of autoclaved cements to a $\mathrm{CO}_{2}$-laden $\mathrm{H}_{2} \mathrm{SO}_{4}$ solution (pH 1.1) at $90^{\circ} \mathrm{C}$.

\section{Experimental procedure:}

\section{1.:Materials :}

The:Boral Material:Technologies Inc supplied both the Class C fly ash (C) and Class $F$ fly ash $(F)$. The chemical constituents of the oxides for these fly ash reactants were as follows: $36.2 \% \mathrm{SiO}_{2}, 19: 1 \% \mathrm{Al}_{2} \mathrm{O}_{3}, 6.7 \% \mathrm{Fe}_{2} \mathrm{O}_{3}, 24.6 \% \mathrm{CaO}, 5: 4 \% \mathrm{MgO}, 1.7$ $\% \mathrm{SO}_{3}, 1.7 \% \mathrm{Na}_{2} \mathrm{O}, 0.5 \% \mathrm{~K}_{2} \mathrm{O}, 3.7 \%$ loss in ignition for $\mathrm{C}$, and, $38.6 \% \mathrm{SiO}_{2}, 38.6 \%$ $\mathrm{Al}_{2} \mathrm{O}_{3}, 12.0 \% \mathrm{Fe}_{2} \mathrm{O}_{3}, 0.5 \% \mathrm{CãO}, 1.4 \% \mathrm{MgO}, 1.9 \% \mathrm{SO}_{3}, 1.5 \% \mathrm{Na}_{2} \mathrm{O}, 1.9 \% \mathrm{~K}_{2} \mathrm{O}$ and 3:4\%: loss in:ignition for $F$. The $x$-ray diffraction (XRD) analysis of these fly ashes showed that the crystalline components of $\mathrm{C}$ consisted mainly of four major phases, quartz: $\left(\mathrm{SiO}_{2}\right)$; tricalcium aluminate $\left(3 \mathrm{CaO} \mathrm{Al}_{2} \mathrm{O}_{3}\right)$, calcium sulfate anhydrate $\left(\mathrm{CaSO}_{4}\right)$, and lime ( $\mathrm{CäO})$, while $\mathrm{F}$ had three major phases, quartz $\left(\mathrm{SiO}_{2}^{\prime}\right)$, mullite $\left(3 \mathrm{Al}_{2} \mathrm{O}_{3} .2 \mathrm{SiO}_{2}\right)$, and hematite $\left(\mathrm{Fe}_{2} \mathrm{O}_{3}\right)$ : Granular sodium polyphosphate, $-\left[-\left(-\mathrm{Na}^{+} \mathrm{PO}_{3}^{-}\right)_{\mathrm{n}}^{-}, \mathrm{NaP}\right]$, was obtainedifrom the Aldrich Chemical Company Inc. The:NaP then was dissolved in water 
to make a $25 \mathrm{wt} \%$ solution for use as the cement-forming acid aqueous reactant. The base reactants, mixed in a twin shell dry blendër, had five C/F ratios; $100 / 0,90 / 10,70 / 30$, 50/50, and $30 / 70$ by weight in preparing the cement slurries, a $66.7 \mathrm{wt} \%$ base reactant for each $C / F$ ratios then was mixed thoroughly with the acid reactant of $33: 3 \mathrm{wt} \%$ ( $25 \mathrm{wt} \%$ NäP solution) at room temperature:

\section{2:2. Measurements:}

The:pore șolutions were extracted from 3 min-aged cement slurries placed in a centrifugal device to measure their $\mathrm{pH}$. Also, three references, $\mathrm{C} /$ water (c/w ratio of $0: 35$ ) and $\mathrm{F} / \mathrm{w}$ ater (same ratio) slurries ; and $25 \mathrm{wt} \% \mathrm{NaP}$ solution, were used to expedite the interpretation of the changes in $\mathrm{pH}$ value by varying the $\mathrm{C} / \mathrm{F}$ ratios. A non-isothermal different scanning calorimeter (DSC) with heating rate of $10^{\circ} \mathrm{C} / \mathrm{min}^{2}$ in $\mathrm{N}_{2}$ gas was : employed to obtain the totalenergy generated in an acid-base exothermic reaction. Fourier transform:infräred spectroscopy (FT-IR)" gave information on which reactant, C or F preferentially reacts with $\mathrm{NaP}$ at temperatures between $20-100^{\circ} \mathrm{C}$. For measuring the compressive strength, water permeability, and porosity; the neat cement slurries were cast in two cylindrical molds, $30 \mathrm{~mm}$ diam and $70 \mathrm{~mm}$ long, for compressive strength testing, and 30 mm diam and $30 \mathrm{~mm}$ long for the othermeasurements; and allowed to harden at: room temperature for 20 hours: The hardened cements were removed from the molds and autoclaved for 24 hours at $250^{\circ} \mathrm{C}$. Their porosity was measured by helium comparison pyconometry Water permeability through the cylindrical cements under a pressure of $202: 65 \mathrm{kNm}^{-2}$ was: determined by the Ruskaliquid permeameter. Compressive strength: test:was:performed using:Instron: The results of these tests and measurements are the average from three specimens. The crystalline phases formed in the autoclaved cements were identified by:XRD: For the acid resistance test; the autoclaved cements $(30 \mathrm{~mm}$ diam: by $60 \mathrm{~mm}$ long) were immersed for: 15 days in the $\mathrm{H}_{2} \mathrm{SO}_{4}$ solution.( $\left.\mathrm{pH}: 1.1\right)$ containing $0.5 \mathrm{wt} \%$ sodium hydrogen carbonate $\left(\mathrm{NaHCO}_{3}\right)$ as a source of $\sim 3000 \mathrm{ppm}$ $\mathrm{CO}_{2}$ at $9.0^{\circ} \mathrm{C}_{2} \mathrm{H}_{2} \mathrm{SO}_{4}^{*}+2 \mathrm{NaHCO}_{3} \rightarrow \mathrm{Na}_{2} \mathrm{SO}_{4}^{\prime}+2 \mathrm{CO}_{2}^{\circ}+2 \mathrm{H}_{2} \mathrm{O}$. To maintain the $\mathrm{pH}$ at 1.1, the $\mathrm{H}_{2} \mathrm{~S}_{4}$ solution was:replenished with a fresh solution every 5 days: The volume proportion of the cements was 1 to 25 . After exposure, the rate of acid erosion of cements 
was determined: from their loss in weight: This result directory provided information on the:effectiveness of phases formed in the cement bodies in minimizing acid erosion.

\section{Rèsults and discussion}

\subsection{Cëment:Slurry}

Before mixing the $\mathrm{NaP}$ solution; with $\mathrm{F}$ blended $\mathrm{C}$, and $\mathrm{C}$ alone, we surveyed the $\mathrm{pH}$ value of the three references; the $\mathrm{NaP}$ 'solution, and the pore solutions extracted centrifugally from water-mixed $\mathrm{C}$ and F slurries (Täble:1). The $\mathrm{NaP}$ solution was acidic, $\mathrm{pH} 4$ 9. The pore solution of $\mathrm{C}$ slurry was basic, $\mathrm{pH} 10.78$; in contrast, the $\mathrm{pH}$ of F was $4: 81$, rendering the acidic slurry: From this:information, it is possible to assume that an acid=base:reaction would take place between $\mathrm{NaP}$ and $\mathrm{C}$, but not between $\mathrm{NaP}$ and $\mathrm{F}$. Correspondingly, the pore solution of a slurry made from a mix of $66.7 \mathrm{wt} \% \mathrm{C}$ and $33.3 \mathrm{wt} \%$ (25 wt\% $\%$ NaP) denoted as the $100 / 0 \mathrm{C} / \mathrm{F}$ ratio, had a nearly neutral $\mathrm{pH}$ of 6.76 ; reflecting the occurrence of an acid base reaction. When $10 \%$ of the total weight of C was repläced by $\mathrm{F}, \mathrm{pH}$ fell to 6.53 . A further drop in $\mathrm{pH}$ was seen as the content of $\mathrm{F}$ was increased. With a $30 / 70 \mathrm{C} / \mathrm{F}$ ratio, the pHof 5.95 was tantamount to a decrease of $\sim 12 \%$ compared with that of the $100 / 0$ ratio slurry:

To obtain the information about the degree of acid-base reaction, our focus centered on computing the total energy generated in the exothermic acid-base reaction between the: $\mathrm{NaP}$ and $\mathrm{C}$ or $\mathrm{C} / \mathrm{F}$ mixtures: Figure 1 shows the non-isothermal $\mathrm{DSC}$ curves over temperature range of $20^{\circ}: 90^{\circ} \mathrm{C}$ for thes slurries made with $100 / 0$ and $70 / 30 \mathrm{C} / \mathrm{F}$ ratios: In this test, these two reactants were separately left for 24 hours at $5^{\circ} \mathrm{C}$ before mixing them: Although the features of both curves highlight the onset temperature of the reaction at $40^{\circ} \mathrm{C}$ and its peak at nearly: $60^{\circ} \mathrm{C}$, one difference between them was the enclosed area of the curve with the baseline, which represents the total heat energy: generated:during the exothermic acid-base;reaction Computer programs were prepared to calculate theoretical exothermic energy, $\Delta H, \mathrm{~J} / \mathrm{g}$, from the enclosed area: The computed $\Delta H$ value of the $100 / 0$ ratio slurry was $818 \mathrm{~J} / \mathrm{g}$, which was almost two-fold higher than that of the 70/30 ration. Figure 2 plots the changes in $\triangle H$ as a function of $\mathrm{C} / \mathrm{F}$ ratio: As: seen, the $\Delta H$ value depended on $\mathrm{C} / \mathrm{F}$ ratio;namely; a decrease in this ratio that means the: incorporation of more $E$ into the blended slurry resulted in the decline of the $\Delta H$ values: 
This finding strongly underscored the fact: that $\mathrm{NaP}$ preferentially reacted with the $\mathrm{C}$ via acid-base activity at temperatures from $20^{\circ}$ to $90^{\circ} \mathrm{C}$, rather than the $\mathrm{F}$.

To support this information; FT:IR study over the frequency range of 1800:400 $\mathrm{cm}^{-1}$ was carried out for $100 / 0,50 / 50 \%$ and $30 / 70$ ratio cements hardened at room temperature, followed by heating at $100^{\circ} \mathrm{C}$ (Figure 3 ) As discussed in the introduction, in.... our study; the hydroxyapatite(HOAp) phase commonly: formed through a two-step ... reaction pathway, acid-base and hydrothermal hydration: Thus; the HOAp obtained from Aldrich Science Corp also was used as the reference sample. The FT-IR spectrum of * 100\% ratio encompassed isix representative bands at $1167,1085,1040,794,604$, and $566 \%$ $\mathrm{cm}^{-1}$. From the reference spectrum of the HOAp (Figure 4); the three bands at:1040, 604, and $566 \mathrm{~cm}^{-1}$ appears to belong to this compound. The major contributor to the remaining. other three bands is the silica [7]. In contrast; the specific features of the spectrum for the 50/50:ratio were as follows: First was the decline of peak intensity at 1040,604 , and:566 $\mathrm{cm}^{-1}$ bandşattributed to HOAp, compared with those of the silica-related bands; second was the appearance of new band at $911 \mathrm{~cm}^{-1}$. We assumed that this new band is due to $F$ : Since the $\mathrm{F}$ reactant in̈cluded three majör chemical components; silica, mullite; and . hematite, we inspected the FT-IR spectra of the last two components as reference samples to definite the assignment of this new:band; our results suggested that the band at 911 cmis was associated with mullite. With the $30 / 70$ ratio cement; the intensity of HOAp-: related bands had strikingly decayed;winile the peak for mullite had intensified.

The above information strongly supported the findings from the DSC study; : namely; $\mathrm{NaP}$ preferentially reacted with $\mathrm{C}$, rather than $\mathrm{F}$ at $\leq 100^{\circ} \mathrm{C}$.

\subsection{Autoclaved Cement:}

An:important:factor governing the mechanical and physical properties of autoclaved cements; and their resistance to hot acid is the identity of the crystalline phases formed:as hydrothermal reaction products in the cement bodies, and also that of the non-reaction prodücts: To obtain this information; we inspected the $100 / 0,50 / 50$, and $30 / 7.7$ ratio cements after autoclaving for 24 hours at $250^{\circ} \mathrm{C}$, by XRD tracings over the diffraction range of $0444-0225 \mathrm{~nm}$ (Figure 5), The "as-received". C was used as the ", reference:sample As expected the:pattern (a) of the C:base reactant revealed the. 
presence of four crystalline components, quartz.( $\left.\mathrm{SiO}_{2}\right)$, calcium sulfate anhydrate: $\left(\mathrm{CaS} \odot_{4}\right)$;lime $(\mathrm{CaO})$, and tricalcium aluminate $\left(3 \mathrm{CaO} \mathrm{Al}_{2} \mathrm{O}_{3}, \mathrm{C}, \mathrm{A}\right)$. When $\mathrm{C}$ was mixed with $\mathrm{NaP}$, followed by autoclaving it, the features of XRD pattern (b) differed from that of $\mathrm{C}$; in particular; there was the appearance of hiydroxyapatite $\left[\left(\mathrm{Ca}_{5}\left(\mathrm{PO}_{4}\right)_{3}(\mathrm{OH})\right.\right.$, HOAp)]-related $d$-spacing:lines and the elimination of the $d$-spacing lines associated with $\mathrm{CaSO}_{4}:$ and $\mathrm{CaO}$, while the prominent lines of quartz and $\mathrm{C}_{3} \mathrm{~A}$ remained unchanged: Accordingly. HOAp as the hydrothermal reaction product is more likely to be formed by the:interaction between the $\mathrm{NaP}$ and $\mathrm{CaO}$ or $\mathrm{CaSO}_{4}$, rather than one between $\mathrm{NaP}$ and $\mathrm{C}_{3} \mathrm{~A}$. Incorporating $\mathrm{F}$ into the $\mathrm{NaP} / \mathrm{C}$ system:led to the formation of an additional reaction product: The pattern (c) from the $50 / 50$ ratio cement can be accounted for the generation of the:zeolitic analcium $\left(\mathrm{NaAlSi}_{2} \mathrm{O}_{6}: \mathrm{H}_{2} \mathrm{O}\right)$ phase as an additional reaction product resulting from the interaction between the $\mathrm{Na}$ from $\mathrm{NaP}$ and the mullite $\left(3 \mathrm{Al}_{2} \mathrm{O}_{3}: 2 \mathrm{SiO}_{2}\right)$ in the $\mathrm{F}$ However; the XRD tracing (not shown) of this cement made at. room temperature did not verify the formation of any zeolitic phases; therefore, the analcime crystals seem to be assembled at high hydrothermal temperature. Again; non-: reacted quartzand: $\mathrm{C}_{3} \mathrm{~A}$ : components were detected, while the intensity of HOAp-related: lines declined because of the decrease in the amounts of available $\mathrm{CaSO}_{4}$ and $\mathrm{CaO}$ base reactants due to the reduction in the proportion of $C$ to $F$ A further decrease in this. proportion to $30 \mathrm{wt} \% \mathrm{C}$ to $70 \mathrm{w}$ \% $\mathrm{F}$ displayed two specific features in the pattern (d): One was a considerable attenuation of the intensity of HOAp $-d$-spacing lines; the other:was a conspicuous growth of the intensity of the analcime-related line in conjunction with the presence of some non-reacted mullitè phases?

Table 2 summarizes the phase compositions for $250^{\circ} \mathrm{C}$-autclaved $\mathrm{NaP}$-modified $100 / 0 ; 70 / 30 \% 50 / 50 \%$, and $30 / 70-\mathrm{C} / \mathrm{F}$ ratio cements. The crystalline phase of the reaction products formed in the autoclaved cements depended primarily on the $\mathrm{C} / \mathrm{F}$ ratio; namely; the major crystalline phase in cements with $100 / 0$ and $70 / 30$ ratios of C/F was HOAp; the 50/50 ratio revealed the generation of the analcime phase as another major reaction : product. Withithe:30/70 ratio, analcium became the principal phase, while the formation. of the HOAp pliase was poor.

Täble 3 lists the changes in porosity, water permeability, and compressive: strength of autoclaved cements as a function of $\mathrm{C} / \mathrm{F}$ ratio. The data revealed that porosity 
tends to decline with the decrease in C/F ratio. In fact; the porosity of $27.5 \%$ for the $100 / 0$ ratio cement;rose $23 \%$ to: $33: 9 \%$ as 30 wt\% of total amount of the $\mathrm{C}$ was replaced by: $\mathrm{F}$ Its further replacement by $\mathrm{F}$ to $70 \mathrm{w}$ \% $\%$ created a porous structure with $41.6 \%$ pores: Relating this; finding to the results from the XRD study, awell-formed HOAp phase contributes to densifying the structure of cement. In contrast; the: development of the analcime phase, coexisting with HOAp by adding $\mathrm{F}$ to $\mathrm{C}$ led to increasing; numbers of pore: in the cement. Thüs, when analcime became the most. dominant phase, as more $\mathrm{F}$ was added to $\mathrm{C}$, the dense structure of the HOAp-associated cement was converted into a porous one As expected, the porous structure not only impaired the compressive strength, but also increased the rate of transportation of water through the cement: In fact; the value of compressive strength for the $30 / 70$-ratio cement " was more than twice as low as that of the $100 / 0$ ratio, while its water permeability of 2.3 . $\mathrm{x} 10^{-3}$ Darcy was equivalent to two orders of magnitude higher than that of the $100 / 0$ ratio..

\section{3:3:Aciderosion}

Basediuponthe:information described above, our focus now shifted to assessing: the resistance of: $\mathrm{F}$-blended and non-blended $\mathrm{C}$ phosphate cements to $\mathrm{CO}_{2}$-laden $\mathrm{H}_{2} \mathrm{SO}_{4}$ solution at $90^{\circ} \mathrm{C}$ for 15 days: weight loss of the cements caused by its acid erosion was measured to evaluate their ability to mitigate the acid erosion. Acid corrosion products formed over a superficiallayer of the cement were brushed off before weighting them: Figure 6 depicts the loss in weight for the $100 / 0 \%, 70 / 30-, 50 / 50-$, and $30 / 70-$ ratio cements: Interestingly; the $100 / 0$ ratio cement possessing the densest structure and the highest compressive strength in this series was most vulnerable to hot:acid attack; loosing 13:1\% of its weight Incorporating F into the C remarkably reduced this amount of acid erosion: With the 70/30 ratio, weight loss was onlya $3.1 \%$, which was equivalent to a decrease of $\sim 76 \%$ compared with that of the $100 / 0$ ratio: A further reduction of weight loss:to $1.9 \%$ :was measure ffrom the $50 / 50$ ratio, while the incorporation of more $\mathrm{F}$ into: thei ( (30/70 ratio) resulted in a weight loss of only $1.5 \%$. In addition, the acid corrosion. product brushed off from the top surfaces of all eroded cements was identified as bassanite $\left(\mathrm{CaSO}_{4} \cdot 1 / 2 \mathrm{H}_{2} \mathrm{O}\right)$ by XRD. 
As: a result; the following important statement can be drawn: the HOAp phase; which plays a pivotal role in conferring a good strength and minimum water permeability of the 100/0 ratio cement; is susceptible to reaction with sulfuric acid and sodium sulfate to form crystalline bassanite as the corrosion product: In contrast; the extent of susceptibility of the analcime; phase formed in the C/F blend cements to hot strong acid is mush; less than that of the HOAp, stronglysuggesting that analcime-rich cement has excellentresistance to hot acid:

\section{Conclusion:}

In sodium polyphosphate (NaP)-modified Class C fly ash (C)/Class $\mathrm{F}$ fly ash cement systems the basic nature of C promoted exothermic acid-base reactions with the " NaP solution as:an acidic cement-forming reactant, This reaction, followed by hydration,. at temperature range of $25: 100^{\circ} \mathrm{C}$, led to the formation of hydroxyapatite $\left[\left(\mathrm{Ca}_{3}\left(\mathrm{PO}_{4}\right) 3(\mathrm{OH}), \mathrm{HOAp}\right]\right.$ as the reaction derivative : In contrast; $\mathrm{F}$ being acidic underwent no acid base reaction with the $\mathrm{NaP}$ Correspondingly, the total exothermic energy, generated by the acid-base reaction depended on the proportion of $C$ to F; namely, incorporating more $F$ into this cement system reduced the output of reaction energy. The $\mathrm{X}$-ray diffraction analysis for the $25^{\circ} \mathrm{C}$-autoclaved cement systems revealed that the $\mathrm{NaP}$, preferentially reacted with two chemical ingredients in the $\mathrm{C}$, calcium sulfate and lime to form: the HOAp, rather than tricalcium aluminate: $\left(\mathrm{C}_{3} \mathrm{~A}\right)$. Thus; autoclaved cement made. with a/C/F ratio of:100/0 included well-formed HOAp as the major crystalline phase coexisting with two remaining non-reacted reactants, $\mathrm{C}_{3} \mathrm{~A}$ and quartz.. The HOAp phase provided the following three properties needed for geothermal well cement, 1) lowering: of porosity; 2), development:of goodicompressive strength; and 3) minimum water permeability: When some amount of $\mathrm{C}$ was replaced with $\mathrm{F}$; the analcime ( $\mathrm{NaAlSi}_{2} \mathrm{O}_{6}: \mathrm{H}_{2} \mathrm{O}$ ) phase:in the zeolitic mineral fámily was formed as the other crystalline. reaction product. Analcime:was synthesized by hydrothermal reactions between the $\mathrm{Na}$ from NäP and the mullite $\left(3 \mathrm{Al}_{2} \mathrm{O}_{3} .2 \mathrm{SiO}_{2}\right)$ in $\mathrm{F}$ at $250^{\circ} \mathrm{C}$. In fact, the phase composition in cement made with 70/30 ratio consisted of HOAp as the major phase and analcime as the: minor phase: The 50/50 ratio cement made by adding more $\mathrm{F}$ had: two major phases, 
HOAp and analcime, and with the $30 / 70$ ratio, the analcime phase became a single major reaction product, while HOAp was poorly; formed.

Although the HOAp phase played a pivotal role in conferring good strength and minimum water:permeability of the cement, it was susceptible to reactions with sulfuric: acidand sodium sulfate; leading to the:formation of crystalline bassanite as the acid corrosion products:in $\mathrm{CO}_{2}$ laden $\mathrm{H}_{2} \mathrm{SO}_{4}$ solution ( $\mathrm{pH} 1.1$ ) at $90^{\circ} \mathrm{C}$. In contrast, the extent of susceptibility of the analcime phase formed in the C/F blend cements to hot strong acid was much less than that of the HOAp; therefore, analcime-rich cement displays an . excellent resistance:tohot acid:

Overall from the viewpoints of having minimum water permeability, a good strength; and a low rate of acid'erosion; the most effective C/F ratio cement was 70/30 in: this series: Thus, cost-effective acid-resistant geothermal well cement could be formulated by a combination of the coal combustion by-products, C and $F$ :

\section{References:}

[1] Sugama T. Hot alkali carbonation of sodium:metaphosphate modified fly ash/calcium aluminate blend hydrothermal cements. Cem Concr Res 1996; 26:1661-71.

[2] Sugama T; Weeber L, Brothers LE. Sodiüm-polyphospate-modified fly ash/calcium aluminate blend cement: durability in wet;: harsh geothermal environements. Mater Lett $2000 ; 44: 45 \div 53$.

[3] Sügama T; Brothers LE, Weber L. Cälciümaluminate cements in fly ash/calcium aluminate blend phosphate cement systems: Their role in inhibiting carbonation and acid corrosion at alow hydrothermal temperature of $90^{\circ} \mathrm{C}$. J Mater.Sci $2002 ; 37: 3163-73$. [4]: Sugama:T;,Brothers:LE, WeberL. Acid-resistant polydimethylsiloxane additive for geothermaliwell cement in $150^{\circ} \mathrm{CH}_{2} \mathrm{SO}_{4}$. solution. Adv Cem Res $2003 ; 15: 35-44$. [5] Schlorholtz:S, Demirel T, Pitt JM. An examination the ASTM lime pozzolanic. acitivity test for class C fly ashs: Cem Concr Res 1.984; 14: 499-504. [6]:Hill $R$, Daugherty $K$. The interaction of calcium nitrate and a class $C$ fly ash during hydration. Cem Concr:Res:1996; 26:1131-43. [7] Färmer:V., Rüssell JD. The infra-red spectra: of layer silicates. Spectrochim Acta $1964 ; 20: 1149: 73$ : 
Table 1. Formulation of NaP modified C/F blendiand non-blend cements' slurries, and the $\mathrm{pH}$ of pore solutions extracted from theirislurries.

\begin{tabular}{|c|c|c|c|c|c|c|}
\hline $\begin{array}{c}\text { Formulation, } \\
\text { No., }\end{array}$ & C/F ratio & C, wt\% & $F, w t \%$ & $\begin{array}{l}25 \% \text { NaP } \\
\text { solution; } \\
\text { wt\% }\end{array}$ & $\begin{array}{l}\text { Water, } \\
\text { wt } \%\end{array}$ & $\begin{array}{c}\text { Pore } \\
\text { solution, } \\
\text { pH }\end{array}$ \\
\hline Rëference 1 & - & $-\cdots$ & - & 100 & - & $4: 90$ \\
\hline Reference 2 & . & 74.1 & $-\cdots$ & - & $25 ! 9$ & 10.78 \\
\hline Reference 3 & - & -. & 7411 & - & $25: 9$ & $4: 81$ \\
\hline 1. & $100 / 0$ & 66.7 & -2 & $33: 3$ & - & 6.76 \\
\hline 2 & 90/10 & 60.0 & 6.7 & 33.3 & - & 6.53 \\
\hline 3 & $70 / 30$ & 46.7 & $20: 0$ & $33: 3$ &.- & 6.38 \\
\hline 4 & $50 / 50$ & $33: 3$ & 33.3 & $33: 3$ & $\cdots$ & 6.14 \\
\hline 5 & $30 / 70$ & 20.0 & $46.7 \ldots$ & $33.3 \ldots$ & - & 5.95 \\
\hline
\end{tabular}

Table:2.. Phase compositions for the $250^{\circ} \mathrm{C}$-autoclaved phosphate-based cements with C/Fratios of $100 / 0,70 / 30,50 / 50$, and $30 / 70$

\begin{tabular}{|c|c|c|c|}
\hline \multirow{2}{*}{ C/Fratio } & \multicolumn{2}{|c|}{ Reaction products } & $\begin{array}{c}\text { Remaining non- } \\
\text { reacted reactant }\end{array}$ \\
\cline { 2 - 4 } & Major phase & Minor phase & Quartz; $\mathrm{C}_{3} \mathrm{~A}$ \\
\hline $100 / 0$ & HOAp & - & Quartz; $\mathrm{C}_{3} \mathrm{~A}$, mullite \\
\hline $70 / 30$ & HOAp & Analcime & Quartz, $\mathrm{C}_{3} \mathrm{~A}$, mullite \\
\hline $50 / 50$ & HOAp Analcime & $-\cdots$ & Quartz; $\mathrm{C}_{3} \mathrm{~A}$, mullite \\
\hline $30 / 70$ & Analcime & HOAp & \\
\hline
\end{tabular}


Täble:3. Changes in porosity, water permeability, and compressive strength of the $250^{\circ} \mathrm{C}$ : autoclaved cements as a function of $\mathrm{C} / \mathrm{F}$ ratio.

\begin{tabular}{|c|c|c|c|}
\hline C/Fratio & Porosity \% & $\begin{array}{c}\text { Water permeability, } \\
\text { Darcy }\end{array}$ & $\begin{array}{c}\text { Cómpressive } \\
\text { strength, MPa }\end{array}$ \\
\hline $100 / 0$ & 27.5 & $5.7 \times 10^{-5}$ & 22.3 \\
\hline $70 / 30$ & 33.9 & $1.2 \times 10^{-4}$ & 20.5 \\
\hline $50 / 50$ & 37.7 & $8.4 \times 10^{-4}$ & 19.4 \\
\hline $30 / 70$ & 41.6 & $2.3 \times 10^{-3}$ & 10.0 \\
\hline
\end{tabular}




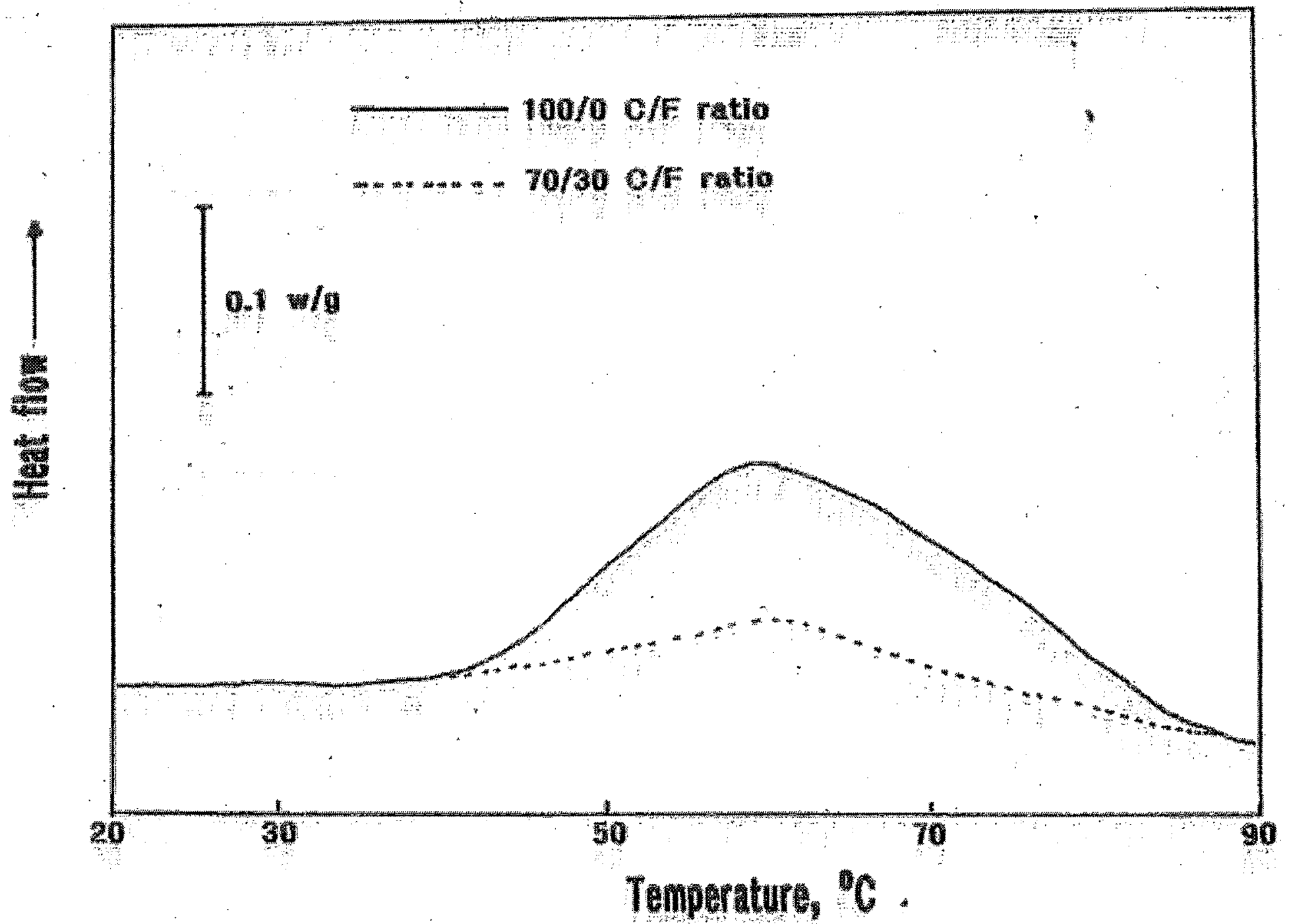

Figure 1. DSC exothermic curves for cement slurries made with C/F ratios of 100/0 and 70/30. 


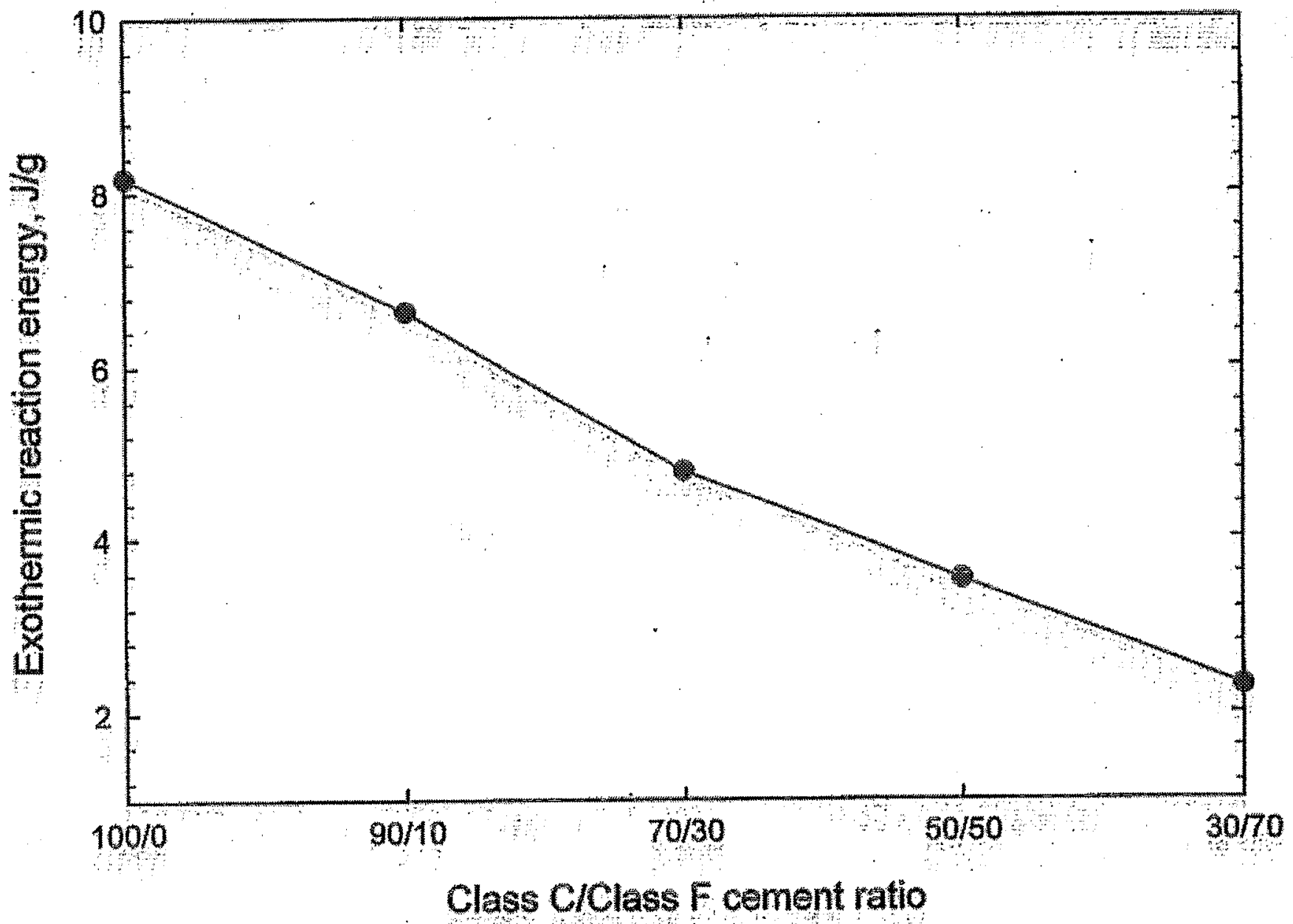

Figure 2. Changes in exothermic reaction energy of cement slurries as a function of $\mathrm{C} / \mathrm{F}$ ratio. 


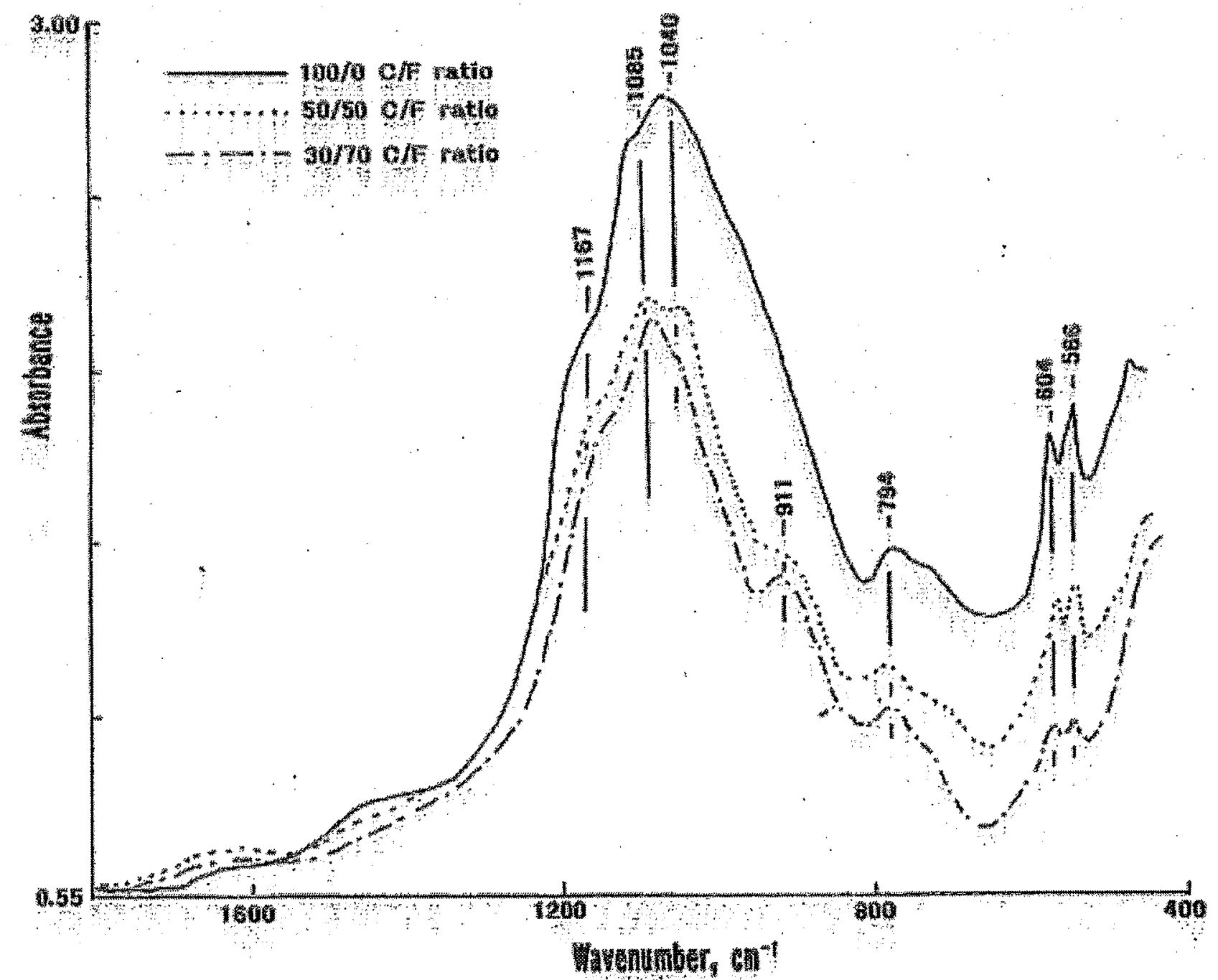

Figure 3. Comparison of FT-IR spectral features for cements made with C/F ratios of 100/0,50/50, and $30 / 70$. 


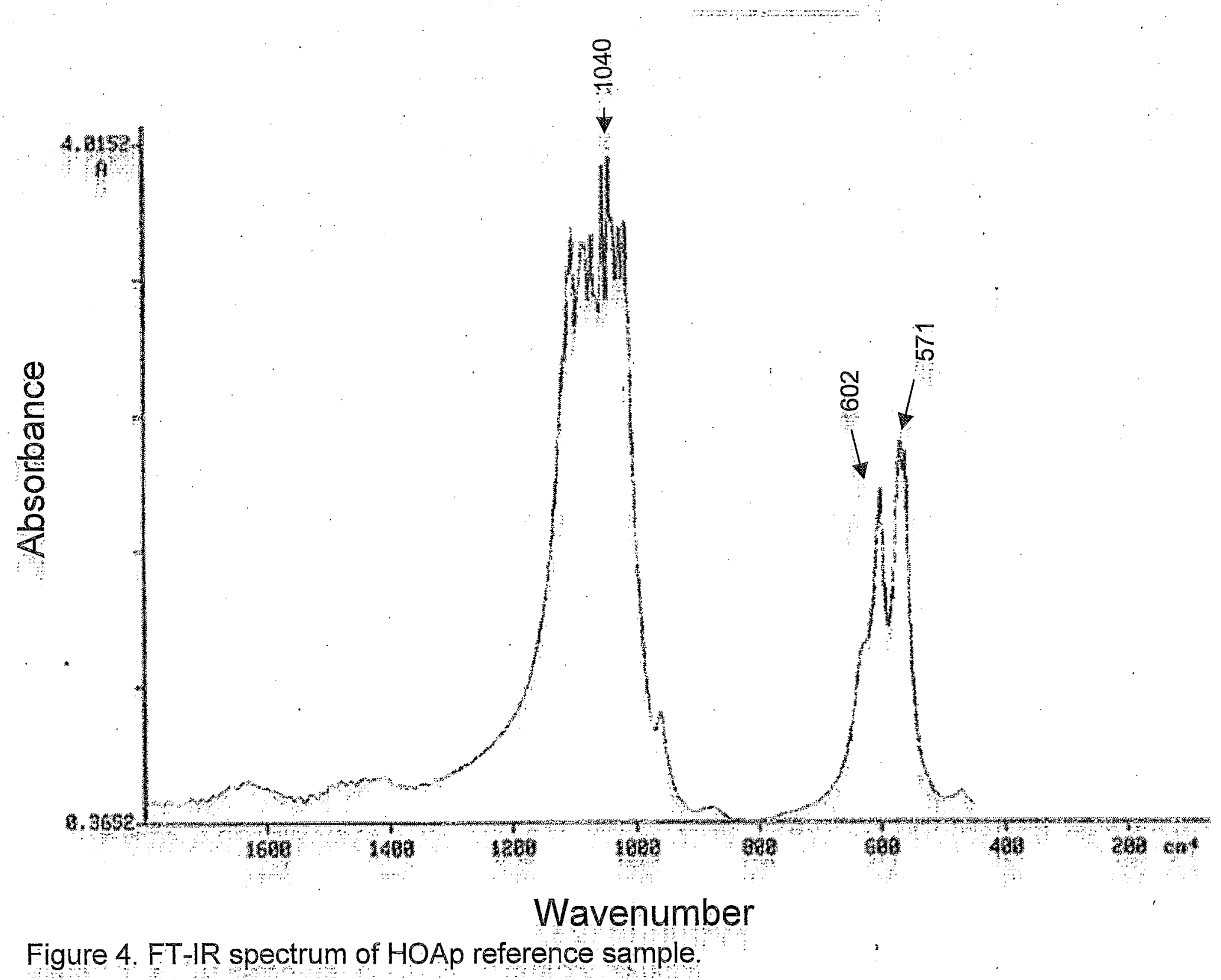




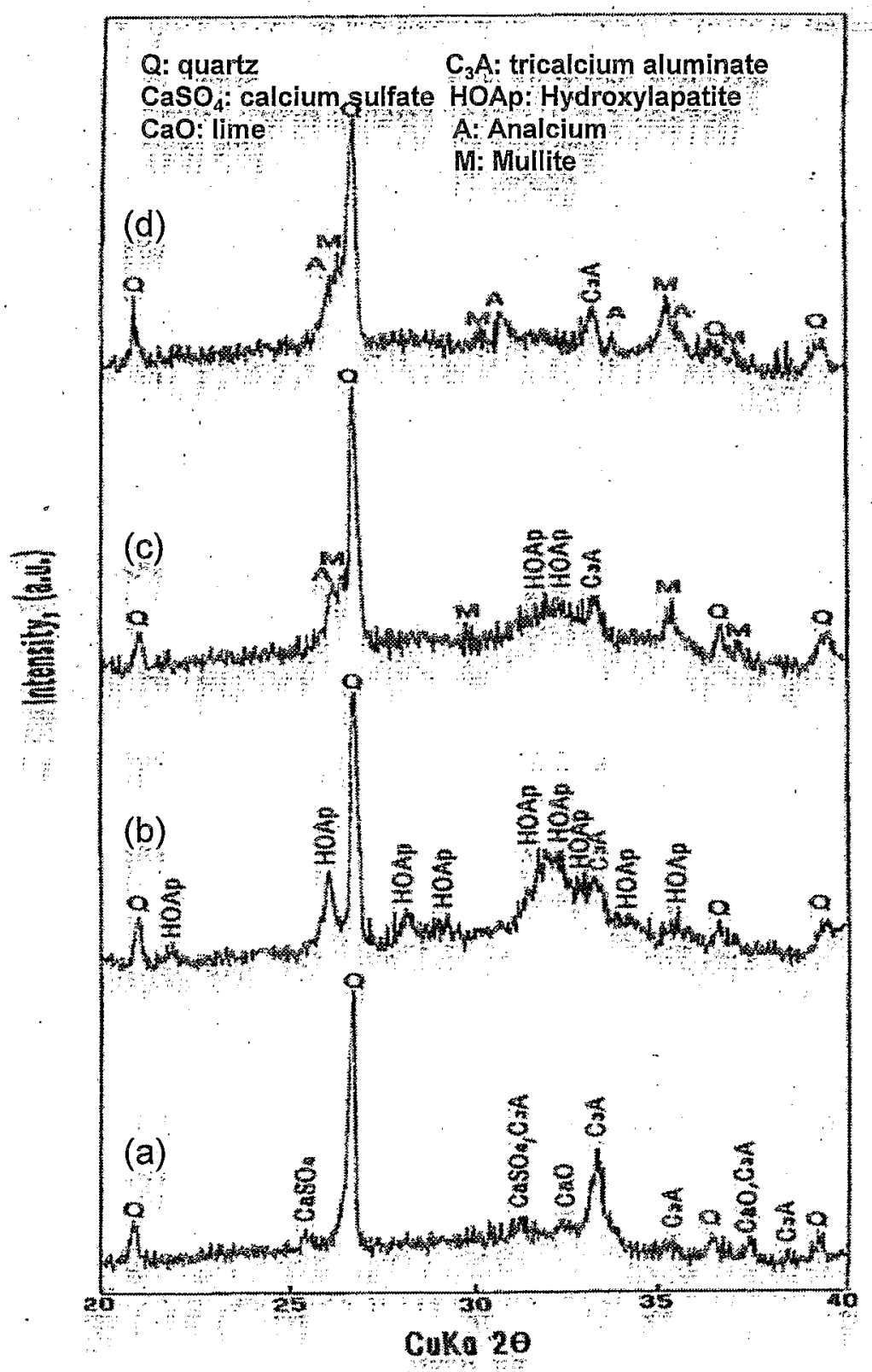

Figure 5. XRD patterns for (a) Class C fly ash, and (b)100/0-, (c) 50/50-, and, (d) 30/70-ratio C/F cements after autoclaving at $250^{\circ} \mathrm{C}$. 


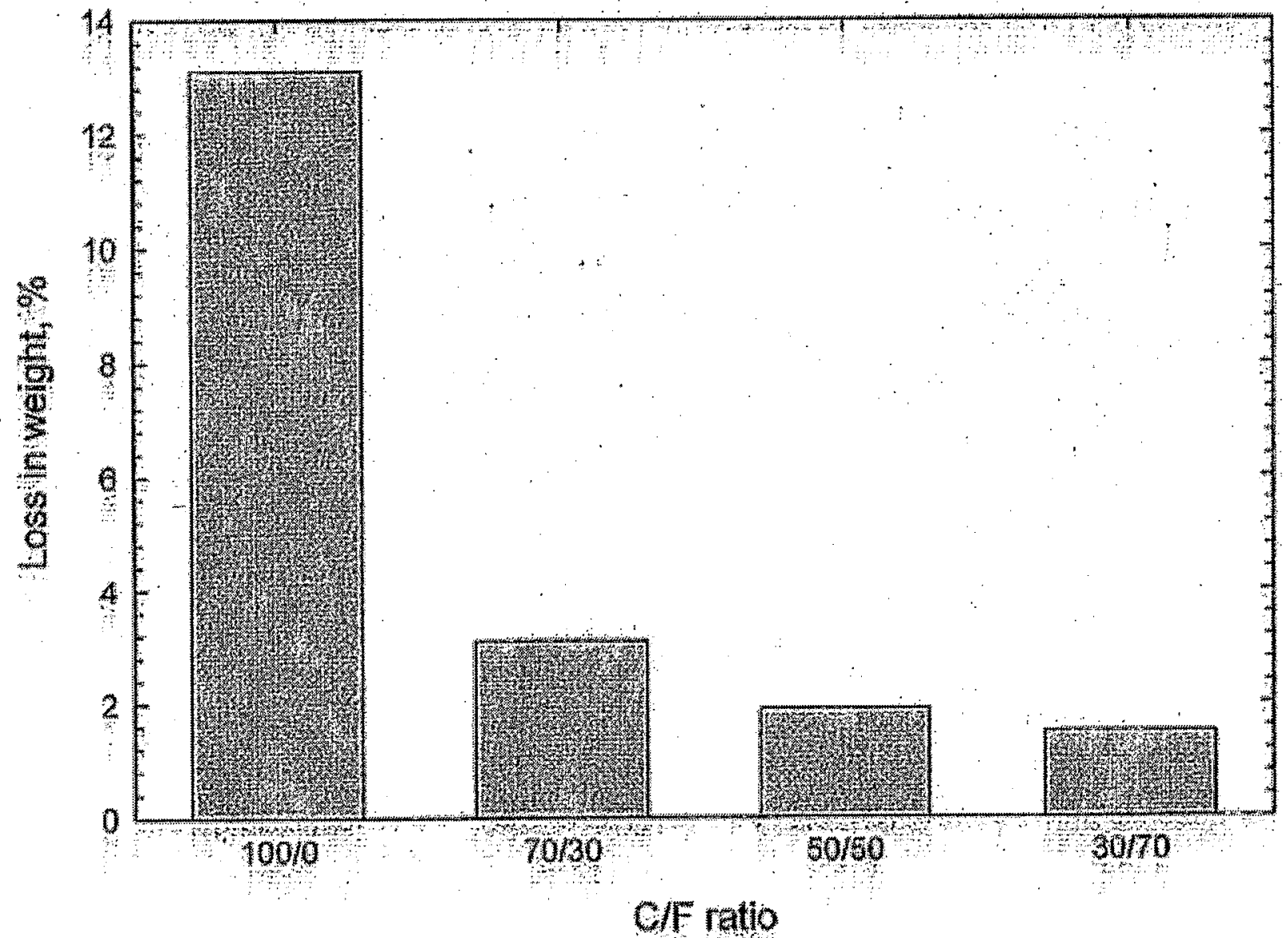

Figure 6. Acid erosion of autoclaved cements made with 100/0-, 70/30-, 50/50-, and 30/70-C/F ratios after exposure for 15 days to $\mathrm{CO}_{2}$-laden $\mathrm{H}_{2} \mathrm{SO}_{4}$ solution $(\mathrm{pH}, 1.1)$ at $90^{\circ} \mathrm{C}$. 